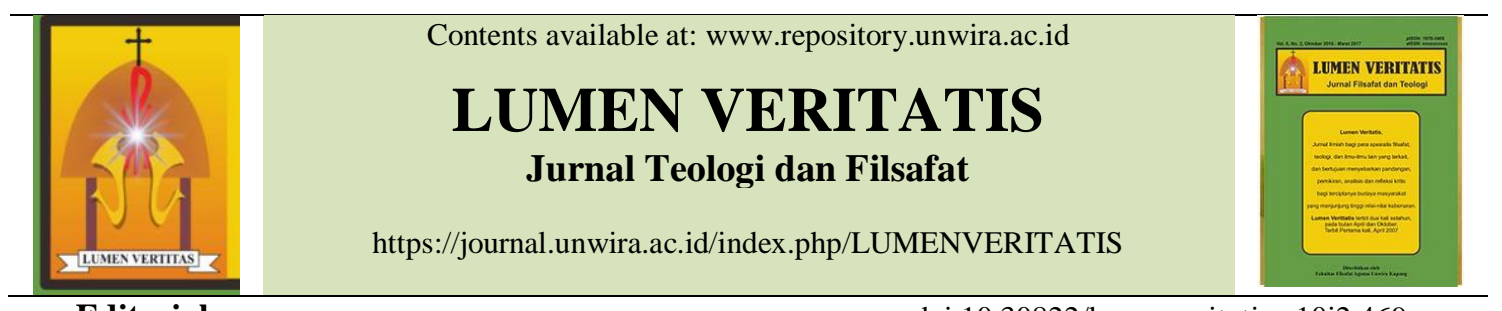

Editorial paper

doi:10.30822/lumenveritatis.v10i2.469

\title{
AGAMA DAN BUDAYA DALAM FILSAFAT
}

(Religion and Culture in Philosophy)

\author{
Okto Kosat \\ Program Studi Ilmu Filsafat, Fakultas Filsafat, \\ Universitas Katolik Widya Mandira Kupang \\ Email: kosatkote11@gmail.com
}

Tulisan yang disajikan dalam Lumen Veritatis edisi kali ini terangkai dalam beberapa fokus kajian yang meliputi kedua tema di atas (Agama dan Budaya). Berbagai eksplosari ilmiah dijalankan demi sebuah tatanan praksis yang bernilai filosofis.

Kiranya keterjalinan kajian-kajian ini membawahi anjuran kebijaksanaan yang telah dicatatkan Aristoteles; First, have a definite, clear practical ideal; a goal, an objective. Second, have the necessary means to achieve your ends; wisdom, money, materials, and methods. Third, adjust all your means to that end. Bahwa, memiliki idealisme untuk sebuah tujuan membutuhkan sarana untuk persesuaian tersebut. Bahwa, agama yang ber-zaman, membutuhkan permenungan yang berbudaya. Ini menjadi bagian penting dari rutinitas ilmiah filsafat. Dan terungkap sebagai penegasan lanjutan bahwa, segala studi dan kajian terhadap berbagai ilmu, harus membawa kita ke dalam kesatuan relasi ilmu-ilmu tersebut.

Kajian tentang Hauteas, selain sebagai perkenalan terhadap kultur keagamaan tradisional, juga membantu terjadinya inkulturasi keimanan orang Kristen. Sementara, kajian tentang Hak dan Tanggung Jawab Atas Lingkungan Hidup, mau memperlihatkan hakikat lingkungan dengan komponen biotik dan abiotik sangat mempengaruhi proses perkembangan seluruh makhluk.

Selanjutnya, kajian terhadap tema Sexual Abuse menjadi salah satu cara untuk mengetahui pengaruhnya dalam hidup keagamaan. Diikuti kajian terhadap Pembentukan Karakter melalui analisis fenomena tradisi lisan yang menekankan adanya perjumpaan manusia dengan kebudayaan yang inkulturatif. Di samping itu, hadir juga sebuah refleksi teologis-filosofis terhadap kepercayaan agama asli di Sumba (Agama Marapu) tentang Perjalanan Jiwa ke 'Kampung Leluhur'. Dan yang terakhir adalah sebuah kajian Fenomenologis dari isu jeritan semesta atas penyalahgunaan dan panggilan untuk bertanggung jawab. 